\title{
Estimating Money Laundering Risks: An Application to Business Sectors in the Netherlands
}

\author{
Joras Ferwerda $^{1}$ (D) $\cdot$ Edward R. Kleemans $^{2}$
}

Published online: 26 June 2018

(C) The Author(s) 2018

\begin{abstract}
Current money laundering policies often rely on the same prescribed instruments for many business sectors. For 'risk based' policies, however, it is important to know in which business sectors money laundering risks are relatively higher. This paper builds upon work conducted as part of Identifying and Assessing the Risk of Money Laundering in Europe (IARM) project and focuses on money laundering risk assessment in the Netherlands. In this paper, we discuss theoretically and empirically how these risks can be estimated and we present results based on data regarding business sectors in the Netherlands. The used risk factors include data on organised crime investments, beneficial owners, and confidential information from the Dutch Tax Office on anomalies in tax declarations by companies. Our results indicate that casinos, hotels, and the art and entertainment sector have the highest money laundering risks in the Netherlands.
\end{abstract}

Keywords Money laundering $\cdot$ Risk assessment $\cdot$ Principal component analysis · Organized crime

JEL classification G32 (Financial Risk and Risk Management) · C38 (Principal Components) · E26 (Informal Economy)

\section{Introduction}

The Financial Action Task Force (FATF) - an intergovernmental body established by the G-7 countries in 1989 - takes the lead in the international fight against money laundering by setting anti-money laundering (AML) policy standards and incentivizing all countries around the

Joras Ferwerda

j.ferwerda@uu.nl

1 Utrecht University School of Economics, P.O. Box 80125, 3508 TC Utrecht, The Netherlands

2 VU School of Criminology, Faculty of Law, Vrije Universiteit Amsterdam, Amsterdam,

The Netherlands 
world to comply with them (Ferwerda 2012, pp. 2-3). Since 2012, each country has to demonstrate that it has a good understanding of the money laundering risks in their country, so that it can apply 'risk-based' AML policies (FATF 2012). The national risk assessments that have been performed so far generally rely on a qualitative analysis (Ferwerda and Reuter 2017; van der Veen and Ferwerda 2016). These qualitative analyses can include a literature review and an overview of regulations, but the results rely heavily on expert opinions.

Using expert opinions to assess money laundering risks has a number of disadvantages. First, virtually all experts asked to perform national risk assessments are part of the fight against money laundering. These experts might overestimate the risks of money laundering hoping to increase their AML budget in the future, or underestimate the money laundering risk for their own institutions eager to gain compliments for their 'good' fight against money laundering. Second, one might wonder whether these experts have sufficient objective information about money laundering activities - that by definition cannot be monitored - to correctly estimate money laundering risks; especially for sectors in which the expert does not work. Third, it is unclear how to aggregate expert opinions, particularly when experts differ in the undetermined amount of knowledge about money laundering risk. Fourth, even when all experts agree on a certain money laundering risk, one may wonder whether this is because this is a real risk or because they all read the same (e.g. FATF typology) reports or news articles. Fifth, using expert opinions can reinforce stereotypes instead of providing new and objective information. Finally, not all experts will always agree to inform the national risk assessment, which implies self-selection problems (see also Leung and Verga 2007). ${ }^{1}$

This paper introduces an innovative, quantitative method to estimate money laundering risks in different business sectors. It is based on the methodology developed by the research project $\mathrm{IARM}^{2}$ and represents the first risk assessment for money laundering including all sectors of the economy, not just those falling under the AML regulations. We apply this method to the Netherlands with a unique dataset gathered specifically for this research. This estimation method for money laundering risks can complement national risk assessments and allows governments to improve their 'risk-based' AML policies.

The literature has recently speculated on which factors increase money laundering risks, such as the use of cash (e.g., Europol 2015; Riccardi and Levi 2017; Soudijn and Reuter 2016) and opaque company ownership (e.g., Blum et al. 1999; van der Does de Willebois et al. 2011; FATF 2014a, 2016; Reuter 2012). ${ }^{3}$ Although these factors are often mentioned in the literature, the empirical testing of these factors is lacking. This paper adds to this literature by putting these hypotheses to the test.

The outline of this paper is as follows. Section "Money Laundering Risks in the Netherlands: A Literature Overview" presents the relevant studies in the Netherlands on money laundering risk and concludes that quantitative assessments are missing. In section "Methodology: Principal Component Analysis to Develop a Composite Indicator", we present our quantitative method to estimate money laundering risks: the principal component analysis (PCA). Section "Operationalization of Money Laundering Risk and Data Collection" presents the operationalization of money laundering risk and data collection. In section "Principal Component Analysis and Results", we show the PCA and discuss its results.

\footnotetext{
${ }^{1}$ Next to this, there is also a more general literature on cognitive biases and heuristics (e.g. Kahneman 2011).

2 This paper is based on research carried out for the EU co-funded project IARM - Identifying and Assessing the Risk of Money Laundering in Europe (www.transcrime.it/iarm).

${ }^{3}$ See FATF 2013a for a full list of factors that could increase money laundering risks.
} 
Section "Sensitivity Analysis" shows the sensitivity and robustness of our analysis. The last section presents a discussion of the main conclusions.

\section{Money Laundering Risks in the Netherlands: A Literature Overview}

We focus our literature overview on the four most important recent publications about AML risks in the Netherlands: The National Threat Assessment by the National Police Services Agency (Soudijn and Akse 2012), a Policy Effectiveness Evaluation by the Court of Audit (Algemene Rekenkamer 2014), the first National AML Policy Monitor published in October 2015 (Decide 2015), and the FATF Mutual Evaluation of the Netherlands (FATF 2014b).

The National Police Services Agency gives an overview of organized crime threats in the Netherlands, including a specific report on money laundering (Soudijn and Akse 2012). The report describes money laundering methods (primarily in a qualitative way, with some figures and indicators), characteristics of money launderers, consequences for Dutch society, relevant factors (abuse of the 500 Euro note), and some specific conclusions about the near future, including the prediction that the basic money laundering methods will remain the same and that only the specific ways in which these methods will be used will change, due to changes in society and regulation (see also Soudijn in this special issue). The report concludes that traditional methods such as loan back and feigning a higher turnover are still frequently used and that methods such as ABC transactions are specifically suited for laundering larger sums of money. Potential new trends may include trade-based money laundering, the use of a specific Dutch legal entity (e.g. 'Stichting', a sort of foundation), new payment methods (such as prepaid debit cards), and leasing cars (whereas leasing companies are not part of the obliged entities in Dutch AML legislation).

The Court of Audit (Algemene Rekenkamer 2014) conducted a policy evaluation on the AML policies in the Netherlands, following up on an earlier, very critical, report (2008) concluding that the prevention of money laundering was insufficient, that the chance that money laundering was detected and punishment was low, and that investigating agencies and authorities made too little use of the opportunities to seize illegal assets. The report concludes that investments have been made into capacity, expertise, and exchange of information, but that the responsible ministers are unable to provide insight into the predominant money laundering risks and the results of AML policies. The advice of the report is to get insight into the predominant money laundering risks in the Netherlands and to start collecting and analysing quantitative and qualitative data on the activities of agencies involved in AML (Algemene Rekenkamer 2014).

The National AML Policy Monitor was partly developed by the Dutch Ministry of Security and Justice as a response to the critical reports of the Court of Audit $(2008,2014)$. This AML Policy Monitor will contribute to the establishment of (performance) indicators of AML activities that are achievable, measurable, and adequate. The first step includes an inventory and interpretation of the AML activities and exchange of information between the actors involved (Decide 2015). The second step involves measuring these activities against the FATF criteria for an effective AML policy. After this first report (Decide 2015), the next version of the monitor aims to specify the performance indicators further, which will improve the functionality of this National AML Policy Monitor.

The FATF 2nd follow-up report (FATF 2014b) of the 2011 Mutual Evaluation of the Netherlands provides an evaluation of the policies and activities implemented in the 
Netherlands in response to the recommendations of this mutual evaluation. The amendments of preventive AML/combating the financing of terrorism (CFT) legislation have (largely) addressed the majority of the shortcomings. The key recommendation of the report is that the Netherlands has made sufficient progress in addressing the deficiencies identified in the earlier mutual evaluation report, such that its overall level of compliance can be assessed at a level essentially equivalent to 'largely compliant'.

We can conclude that all these studies lack a sufficient quantitative analysis to assess money laundering risks. This paper contributes to this literature by presenting how one can use quantitative analyses to assess money laundering risks in different business sectors.

\section{Methodology: Principal Component Analysis to Develop a Composite Indicator}

Our research method is based on the Organisation for Economic Cooperation (OECD) methodology on developing composite indicators (OECD and JRC 2008). The idea is to use a PCA with many variables that are all related to money laundering risks. The PCA can only be used to estimate relative risks, in this case, relative to other business sectors.

We start with developing a theoretical framework and selecting relevant variables for the PCA. The variables are grouped in threats like organized crime investments in the sector and vulnerabilities like cash-intensive businesses that make a sector attractive for money laundering - in line with the FATF taxonomy (CSF, 2014a; FATF, 2013; Dawe, 2013b). ${ }^{4}$ The focus is on the eventually calculated composite indicator for money laundering risk and we use a unique dataset that has been collected specifically for this research. Some of these indicators are so unique that it is worthwhile to analyse them separately to determine what these indicators are telling us, especially the indicators on the opacity of businesses in each sector, calculated by aggregating micro-level company data from the Orbis database, acquired via the Bureau van Dijk.

We apply PCA for money laundering risks to 83 business sectors ${ }^{5}$ in the Netherlands. The Netherlands is rather unique in sharing sensitive data by government agencies for scientific research. For instance, for this research, the Dutch Tax Office shared data on controls of tax declarations of businesses in the Netherlands. This data includes the number of visits to check the financial reports of businesses for each year and how often anomalies have been detected. This data is very sensitive, because it would inform companies about the chance to be detected for (tax) frauds. ${ }^{6}$ Due to its sensitiveness, we only show the results of our analysis at an aggregated level.

\footnotetext{
${ }^{4}$ In line with most national risk assessments and the on-going EU Supranational Risk Assessment, the focus is on threats and vulnerabilities. We leave out the consequences as suggested in the FATF guideline (FATF 2013b) and explained in Savona and Riccardi (2017 chapter 1)

${ }^{5}$ The business sector classification is the international standard level 2 Nomenclature générale des Activités dans les Communautés Européennes (NACE) classification, i.e. NACE divisions. This disaggregation level is the best compromise in terms of guaranteeing statistical significance and data availability (e.g. each sector should have sufficient companies for which data is available). Those business sectors that include on average less than 10 registered companies according to the company data from the Statistics Bureau Netherlands (CBS) in the quartiles of 2014 and 2015 have been removed.

${ }^{6}$ We would like to thank the Dutch Tax Office for providing the data and Jan Glimmerveen for his help in acquiring the data.
} 
The Netherlands has been a pioneer in money laundering research; the FATF (2013b, pp. 54-55) guidance for national risk assessments specifically mentions three studies in the Netherlands. The first national risk assessment of money laundering was published (van der Veen and Heuts 2017) after a pilot study on methods and data for the national risk assessment (van der Veen and Ferwerda 2016). The first national risk assessment is primarily based on qualitative methods, but proclaims the ambition to make subsequent national risk assessments rely more and more on quantitative analyses. We hope to contribute to that ambition with this research. The second national risk assessment is expected to start in 2018 and will be finished after the publication of this paper.

\section{Operationalization of Money Laundering Risk and Data Collection}

After a review of academic literature, institutional reports, investigative and judiciary evidence, and validation by experts, we identify a number of money laundering risk factors for business sectors in the Netherlands. We only consider those risk factors that could be operationalized with available and applicable data. For this reason, the statistical analysis does not cover some risk factors that are deemed important in the literature (such as irregular labour), because there are no good measures available for Dutch business sectors.

For money laundering threats, we focus on organized crime infiltration and corporate fraud. Money laundering vulnerabilities include cash intensiveness, profitability, and complexity of business ownership. We operationalize some of these risk factors into multiple proxy variables in order to allow for their measurement and analysis. The selected risk factors and proxy variables are shown in Table 1 and will be explained in further detail below.

The methodology relies on the concept of relative risk, which means that the money laundering threats and vulnerabilities should be weighted for the size of the business sector if the risk factors are not yet a relative measure (such as cash intensity or profitability). Therefore, variables have been transformed into ratios on relevant control variables (e.g.

Table 1 Risk factors and proxy variables for money laundering risks in Dutch business sectors

\begin{tabular}{|c|c|c|c|}
\hline ML risk factor & Proxy variable & Source & Years \\
\hline \multirow[t]{3}{*}{ Organized crime (OC) infiltration } & $\begin{array}{l}\text { OC infiltration evidence } \\
\quad(\mathrm{OCM})\end{array}$ & $\begin{array}{l}\text { OC monitor (Kruisbergen et al. } \\
\text { 2012) }\end{array}$ & 1996-2012 \\
\hline & $\begin{array}{l}\text { OC infiltration evidence } \\
\quad(\mathrm{OCP})\end{array}$ & $\begin{array}{l}\text { OC portfolio (Savona and } \\
\text { Riccardi 2015) }\end{array}$ & 1995-2012 \\
\hline & $\begin{array}{l}\text { Administrative denials } \\
\text { (BIBOB) }\end{array}$ & BIBOB annual report 2014 & 2014 \\
\hline Corporate fraud & Corporate tax anomalies & Dutch Tax Office & $2011-2015$ \\
\hline Cash intensiveness & Cash/total assets ratio & Bureau van Dijk (BvD) & $\begin{array}{l}\text { Last } \\
\quad \text { available }\end{array}$ \\
\hline \multirow[t]{3}{*}{$\begin{array}{l}\text { Complexity of business ownership } \\
\text { (BO) }\end{array}$} & BO distance & VU elaboration BvD data & $\begin{array}{l}\text { Last } \\
\quad \text { available }\end{array}$ \\
\hline & BOs' risk score & $\begin{array}{l}\text { VU elaboration BvD and TJN } \\
\text { data }\end{array}$ & $\begin{array}{l}\text { Last } \\
\quad \text { available }\end{array}$ \\
\hline & Shareholders' risk score & $\begin{array}{l}\text { VU elaboration BvD and TJN } \\
\text { data }\end{array}$ & $\begin{array}{l}\text { Last } \\
\quad \text { available }\end{array}$ \\
\hline Profitability & EBITDA margin ratio & Bureau van Dijk & $\begin{array}{l}\text { Last } \\
\quad \text { available }\end{array}$ \\
\hline
\end{tabular}

Source: the authors 
number of companies or total assets). Consequently, a min-max normalization is applied, making all values between 0 and 1 , with 0 for the lowest relative value and 1 for the highest. ${ }^{7}$

\section{Money Laundering Threats}

For an analysis on business sectors, threat variables are particularly hard to find, since one cannot use crime data as one can for a geographical analysis (Savona and Riccardi 2017, p. 36). Predicate offences happen in a certain region, but not in a specific sector. ${ }^{8}$ We eventually were able to find four proxies for money laundering threats.

One of the most important sources for insights into organized crime in the Netherlands is the Dutch Organized Crime Monitor (Kruisbergen et al. 2012). Kruisbergen, Kleemans, and Kouwenberg (2015) discuss national and international studies on investments of organized crime offenders and use empirical data on 150 cases from the Dutch Organized Crime Monitor to give empirical insight into the choices organized crime offenders make when they invest their money in the legal economy. This data includes 1196 individual assets of many hundreds of suspects. The study sheds light on what kind of assets offenders purchase and where these assets are located. The results are used to assess the tenability of different theoretical approaches and assumptions that are present in the literature: the standard economic approach ('profit'), the criminal infiltration approach ('power'), and social opportunity structure ('proximity'). The results of this study show that offenders primarily invest in their country of origin or in their country of residence. Furthermore, their investments consist of tangible, familiar assets, such as residences, (other) real estate, and small companies from well-known sectors. Financial investments such as stocks listed on the stock exchange were only found in a small number of cases. In other words, offenders usually stay close to home with their investments. So, instead of profitability and power, proximity seems to be a better description of their investment choices. We use the data of Kruisbergen et al. (2015) for our current study. ${ }^{9}$ For 113 of the 150 organized crime cases in this dataset, information is available on investments in companies and to which business sectors these companies belong. ${ }^{10}$ We find, in Section "PCA and Results" of this article, high money laundering risks in sectors that are close to criminals, such as casinos, hotels, bars, and brothels.

Another proxy variable for organized crime infiltration comes from data of an international EU co-funded research project called Organized Crime Portfolio (OCP; see Savona and Riccardi 2015). The OCP project draws conclusions from a database built by collecting information on organized crime investments from publicly available sources (research reports, newspapers, etc.). This means that there is some overlap of the data with the Organized Crime

\footnotetext{
${ }^{7}$ This min-max normalization is done with the following formula: normalized value $=$ (value - lowest value of proxy) / (highest value of proxy - lowest value of proxy). Using other normalization methods do not alter the results significantly; see also the sensitivity analysis in Section "Sensitivity Analysis".

${ }^{8}$ Obviously, some crimes do happen in a specific sector, like stealing from the company or specific types of fraud. But these crimes are not the money laundering threats for the business sectors we are looking for here; these are merely the source of crime money that can later on threaten other business sectors.

${ }^{9}$ We thank Edwin Kruisbergen and the Research and Documentation Center (WODC) of the Dutch Ministry of Justice and Security for providing us the detailed data and allowing us to use them for this research.

${ }^{10}$ To make the data comparable across sectors, we divide the count by the total number of registered companies in that business division. In some cases, we did not have data specified at business division level, but only at the business section level. In those cases, we divide the number of invested companies by the sum of all the registered companies in all the different divisions belonging to that section and applied that result to all the divisions belonging to that section.
} 
Monitor in the Netherlands, which are also covered by the OCP project. ${ }^{11}$ The correlation between the two variables of 0.26 makes us conclude that they are sufficiently different and that we can therefore include both in our analysis.

The last proxy for organized crime infiltration comes from a specific administrative law in the Netherlands, called BIBOB. Particularly in Amsterdam in the 1990s, there were concerns about criminals taking over (parts of) the city centre (Fijnaut et al. 1998)). Consequently, to limit criminal investments in businesses such as bars and restaurants, the Netherlands implemented the so-called BIBOB Act that gives administrative institutions the opportunity to revoke or reject licenses when there is suspicion of criminal involvement. Since the BIBOB Act came into effect, the Netherlands has become the second European country, after Italy, with administrative regulations against organized crime (Ferwerda and Unger 2016). An internal evaluation of the BIBOB Act showed that the possibility of being screened discouraged several applicants from continuing the application process for a license and possible displacement effects (Huisman and Nelen 2007). We use the number of BIBOB investigations in different business sectors as a proxy for organized crime infiltration (see Landelijk Bureau BIBOB 2014). ${ }^{12}$

The last proxy variable for money laundering threat is information on corporate tax anomalies. Money launderers using a company for their money laundering operations have a different objective than normal business owners that generally aim to maximize profits or the size of the company. This difference should somehow be reflected in their behaviour, which might trickle down into the administration of a company. A money launderer might use some dirty funds - such as for paying employees with black salaries or adding cash to the registerand has to find a way to account for that; some 'cooking of books', i.e. accounting manipulations, might therefore be needed. In an attempt to capture this behaviour, we use data on tax inspections. If a tax inspector finds a mistake in the financial administration of a company, a correction of the tax declaration is made. It was possible to acquire confidential data from the Dutch Tax Office on how many companies have been visited for a financial inspection ${ }^{13}$ and how often corrections to the financial statements were made in each business sector (at division level) for the years 2011-2015. ${ }^{14}$

\section{Money Laundering Vulnerabilities}

Cash-based economies are more vulnerable to money laundering (Savona and Riccardi 2017, p. 38). Cash is a facilitator for committing crimes (first of all tax evasion) and for laundering the proceeds of crime (FATF 2010; Savona et al. 2016; Gilmour and Ridley 2015; Gilmour

\footnotetext{
${ }^{11}$ However, these cases are reclassified by the authors of OCP based on the short descriptions of all cases included in the Organized Crime Monitor (in an appendix), since they did not have access to the (unpublished) original data classification that is used in this research.

${ }^{12}$ By definition, this data only applies to a limited number of business sectors: sectors that are eligible for a BIBOB investigation. Which sectors are eligible for a BIBOB investigation is not nationally prescribed, but is different from city to city. We would prefer to use data on the results of these investigations (how often in each business sector licenses are revoked or rejected), but unfortunately these are unavailable due to confidentiality. ${ }^{13}$ Official term in Dutch for such an investigation is "boekenonderzoek".

${ }^{14}$ It was not possible to know which corrections were made and whether it was to the advantage or disadvantage for the checked company, but only the mere amount of corrections was available. To construct a comparable proxy variable across sectors, the number of corrections in each sector for the five years 2011-2015 was added up and then divided by the total number of inspections in that sector in the same period. Obviously, it is not possible to know whether these corrections indeed are (part of) corporate fraud or money laundering schemes: this is just the best indicator available for such a complex and multifaceted phenomenon as corporate tax fraud.
} 
2014; Transcrime 2013; Riccardi 2014; Ferwerda 2012, p. 5). Cash is hard to trace and therefore helps disguising the criminal sources of profits, making financial investigations and asset seizures harder (Riccardi and Levi 2017; Europol 2015; U.S. Department of the Treasury 2015; Soudijn and Reuter 2016). Measuring the level of cash intensity at the business sector level is not easy. The proxy adopted here is an indirect measure of how much companies in a certain sector detain assets in cash: the average ratio of cash-to-total assets. Other measures of liquidity are, for example, current assets over total assets. It has been found that current assets over total assets is a meaningful proxy for cash intensiveness in Italy (Savona and Riccardi 2017), but in the Netherlands, the same patterns cannot be found (most of the evidence on current assets is limited to Italian mafias) and therefore we conclude that cashto-total assets is a better proxy.

According to some scholars, profitable sectors might be more prone to money laundering, because the goal is to create 'white' profits and because upcoming markets where the regulations are still in development are interesting for criminals (for a review, see e.g. Kruisbergen et al. 2015; Masciandaro et al. 2007, p. 7; Unger and Rawlings 2008; Williams 2001). We are aware that the empirical evidence showing correlation between money laundering/criminal infiltration and an industry's profitability is weak (e.g. see Riccardi 2014; Donato et al., 2013; Transcrime 2013). The sensitivity analysis (see Section "Sensitivity Analysis") shows that excluding profitability from the analysis does not alter the results significantly for the Netherlands. To measure a sectors' profitability, average gross profit (data from $\mathrm{BvD}$ ) is divided by the total turnover. To make sure that accounting and taxation differences between sectors do not skew our results, we use the standard EBITDA ${ }^{15}$ measurement for gross profit.

Complex and extensive corporate structures, especially if set up in risky jurisdictions with low levels of financial transparency, are helpful for concealing illicit flows and hiding beneficial ownership (BO; see e.g. FATF 2016, 2014a; Unger et al. 2013; Riccardi and Savona 2013; van der Does de Willebois et al. 2011; Blum et al. 1999; EBOCS Consortium 2015; EURODAD 2015; van Koningsveld 2015). The need for more punctual and transparent information on BO has been stressed by FATF recommendations (FATF 2012) and acknowledged at the EU level in the updated version of the AML Directive (EU Directive 2015/849). However, problems of accessing data on ownership across different business registers and jurisdictions remain (Riccardi and Savona 2013; EBOCS Consortium 2015). We use three innovative proxies for the complexity and opacity of BO: The number of 'steps' between a company and its beneficial owner ${ }^{16}$ (called BO distance), business owners in risky jurisdictions (called BOs' risk score) and shareholders in risky jurisdictions (called shareholders' risk score). ${ }^{17}$ The analysis on the nationality of shareholders and beneficial owners covers 450,000 shareholders and 25,000 BOs. ${ }^{18}$ We elaborate on the proxies for opacity below.

\footnotetext{
15 EBITDA stands for Earnings Before Interest, Taxes, Depreciation and Amortization.

${ }^{16}$ Beneficial owners in the BvD definition refer to owners who hold a minimum of $10 \%$ at the first level of a company. When BO distance equals 1 , the company is directly controlled by its BO, or BOs (see Savona and Riccardi 2017 for details).

${ }^{17}$ Our calculations of BO and shareholder risk score are based on the Financial Secrecy Score of Tax Justice Network (2015). See Savona and Riccardi (2017) for details.

${ }^{18}$ Initially, the percent of foreign owners of businesses in each sector was also considered as a proxy of money laundering vulnerability, because the higher the number of foreign shareholders, the more difficult it is to trace the $\mathrm{BO}$ and therefore the higher the risk. However, this variable would overlap to a high extent (correlation of 0.97) with the number of shareholders and BOs from risky jurisdictions. Therefore, it was decided not to include it.
} 
The proxies on opacity of BO should indicate the dubious companies that have an unnecessarily complex ownership structure. One of the important findings in our research is that we cannot rely on just using indicators of complexity (as suggested in the literature, see e.g. FATF 2016, 2014a; van der Does de Willebois et al. 2011; Blum et al. 1999), because bigger multinational companies have more complex ownership structures in general. Just using indicators of complexity would not indicate business sectors with money laundering risk, but business sectors with more multinationals. For this reason, we correct proxies by a measure of company size (specifically, the average total assets). To illustrate this, the figures below show the (unweighted) average BO distance (Fig. 1) and the average company size (Fig. 2). As one can see, the top three sectors in terms of BO distance are mining, finance and energy (see Fig 1), but these are also exactly the sectors with the biggest companies (see Fig. 2). This indicates that, as expected, larger companies have on average a more complex ownership structure. Figure 3 weights the BO distance per business sector by average company size (scale is normalized to $0-100$ to facilitate interpretation). Then, the sectors entertainment (which includes casinos), other services, and hotels and bars become the top three.

\section{Principal Component Analysis and Results}

We adopt a PCA approach to develop a composite indicator of money laundering risk. PCA is a multivariate data analysis technique used, in a way similar to other approaches (e.g. factor analysis), to reduce the information contained in large datasets into a smaller number of components (or factors, in factor analysis), each of them able to summarize a specific phenomenon explained by a range of related variables (see appendix Table 5). For doing so, PCA uses an orthogonal transformation of the related variables into a set of principal components which are uncorrelated to each other. Specifically, a Pearson (n) PCA with

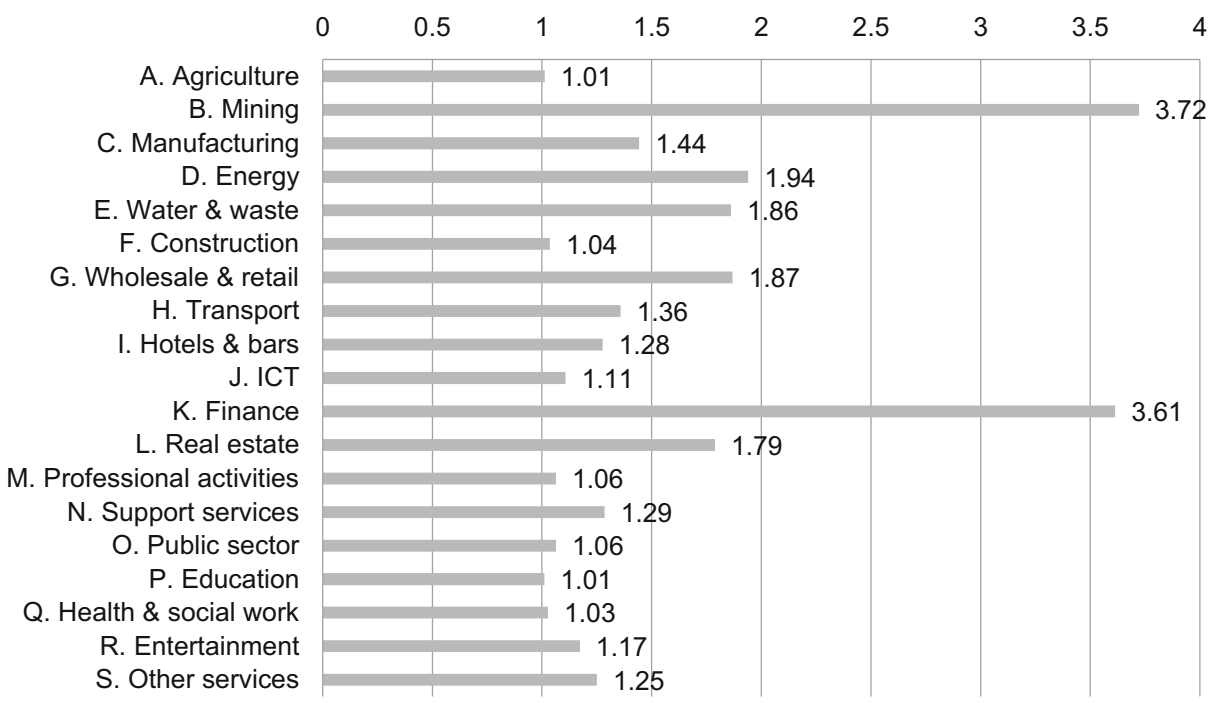

Fig. 1 Average BO distance per business sector. Source: VU Amsterdam elaboration of BvD data. For visibility, we show the 19 NACE (rev. 2) sections, instead of the 83 NACE (rev. 2) divisions on which the eventual analysis is performed. Last available year. BO distance of 1 means direct ownership of a beneficial owner into a company without intermediate ownership layers 


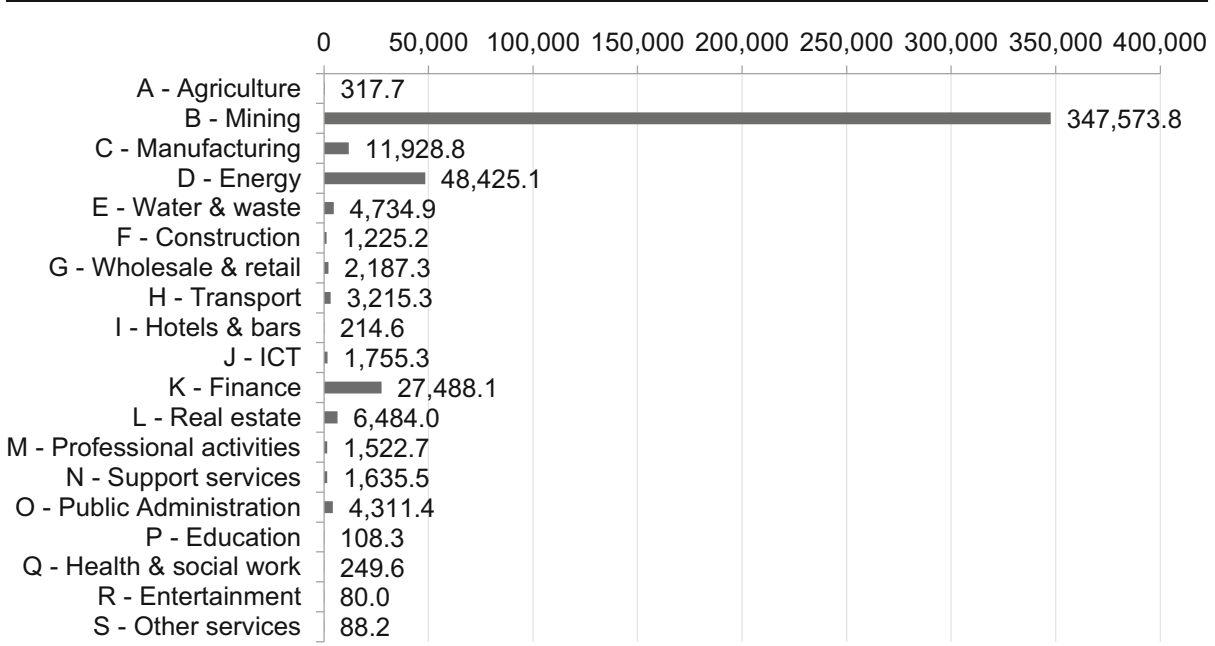

Fig. 2 Average company size (total assets in thousands of euro) per business sector. Source: VU Amsterdam elaboration of BvD data. For visibility, we show the 19 NACE (rev. 2) sections, instead of the 83 NACE (rev. 2) divisions on which the eventual analysis is performed. Last available year. Average total assets in thousands of euro

varimax rotation is performed. This PCA helps to downsize the number of variables into a smaller number of components (Kabacoff 2015; OECD and JRC 2008; Rencher 2002), which would correspond to sub-dimensions of money laundering risk. The number of principal components is selected on the basis of generally accepted standards such as the so-called Kaiser-Harris criterion (see Kabacoff 2015; OECD and JRC 2008; Rencher 2002). The results of the PCA are summarized in Table 2. For visibility, we highlight the variables with a nondiscretionary weight of more than 0.5 (and those between 0.3 and 0.5 with a lighter colour).

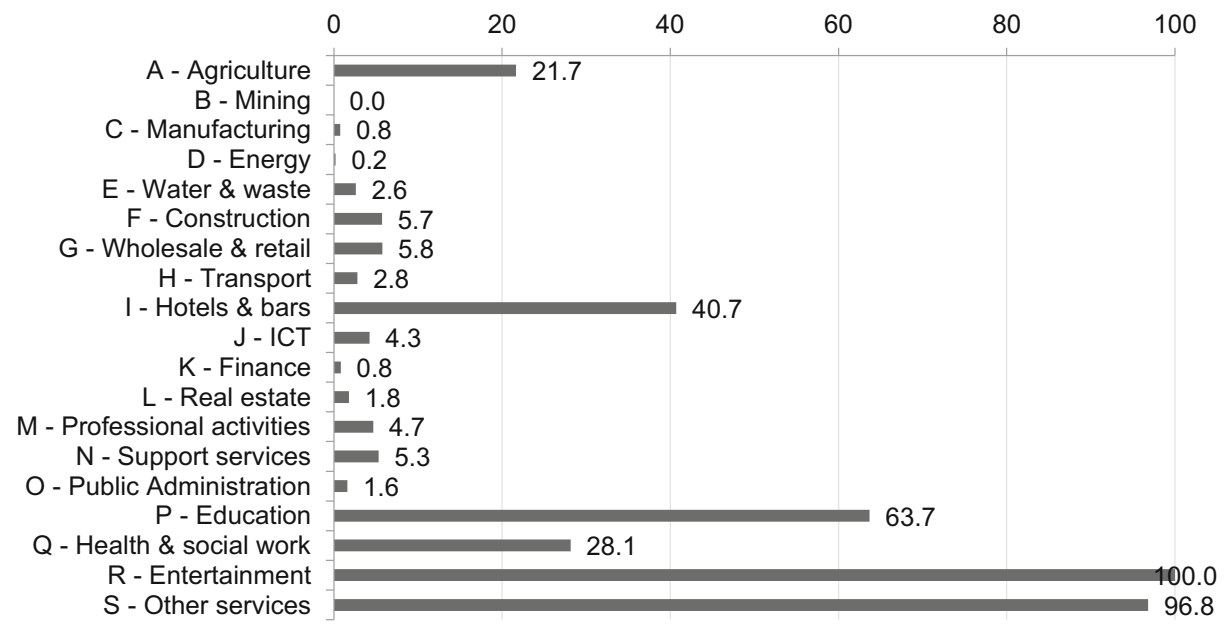

Fig. 3 Average BO distance per business sector weighted by average company size. Source: VU Amsterdam elaboration of BvD data. For visibility, we show the 19 NACE (rev. 2) sections, instead of the 83 NACE (rev. 2) divisions on which the eventual analysis is performed. Last available year. A disadvantage of this correction is that the unit of measurement of the statistic becomes harder to interpret; therefore, the scale is normalized to 0100 
Table 2 Relevant components calculated with principal component analysis

\begin{tabular}{lrrr}
\hline & PC1 & PC2 & PC3 \\
\hline OC infiltration OCM & 0.35 & 0.04 & -0.64 \\
OC infiltration OCP & 0.89 & -0.07 & -0.02 \\
Administrative denials & 0.92 & 0.06 & -0.02 \\
Corporate tax anomalies & 0.00 & 0.25 & 0.47 \\
Cash intensity & 0.31 & 0.31 & 0.55 \\
BO distance & -0.05 & 0.55 & 0.39 \\
Shareholders' risk score & -0.11 & 0.89 & 0.03 \\
BOs' risk score & 0.42 & 0.68 & -0.16 \\
Profitability & 0.01 & -0.31 & 0.59 \\
Eigenvalue & 2.22 & 1.83 & 1.26 \\
Proportional variance $(\%)$ & 24.62 & 20.35 & 14.02 \\
Cumulate variance $(\%)$ & 24.62 & 44.97 & 58.99 \\
\hline
\end{tabular}

Source: calculated by the authors. The selected principal components with an eigenvalue $>1$ are shown, in line with Kaiser (1960).

Table 2 shows three principal components that we interpret (see below) as 'organized crime infiltration and beneficial owner secrecy' (PC1), 'opacity of business ownership' (PC2), and 'cooking the books' (PC3). The three principal components together explain about $60 \%$ of the variability. The PCA shows that the risk factors on the threat of organized crime investments are distinct from those on the threat of corporate tax anomalies in the sense that they do not appear in the same components. The combination of organized crime infiltration with $\mathrm{BO}$ secrecy is shown to be the main component (PC1) of money laundering risk. Opacity of BO (PC2) is indicated as the second most important component of money laundering risk. The third component of money laundering risk points towards cash-intensive and profitable companies with tax anomalies. We can label ${ }^{19}$ this component 'cooking the books' (PC3). Interestingly enough, this component is negatively related to organized crime investments (OCMs), indicating that the business sectors related to cooking the books are not those in which the police more often finds organized crime infiltration. This component could refer to a very traditional method of money laundering, namely adding cash to the register (see e.g. Ferwerda 2012). Adding cash to the register is a) harder to detect in cash-intensive sectors, b) creates extra profits, and c) creates a difference between the actual business of the company and its financial statements, which can be labelled as a tax anomaly when detected. This PCA might therefore encompass different money laundering aspects, modi operandi, or typologies. Although we are eventually interested in the overall money laundering risk per sector, it is interesting to gain some insight in how these different risk components vary across sectors, as shown in Table 3.

These results seem to indicate that the extracted principal components capture different aspects of money laundering risk: there is not a single sector that appears in the top 10 of each component. The most important component - organized crime infiltration and BO secrecyhas, as expected, in its top 10 many sectors that are also mentioned in the literature on organized crime in the Netherlands (Ferwerda and Unger 2016; Kruisbergen et al. 2015), but also some unexpected ones (such as manufacture of other non-metallic mineral products and public administration and defence). For the other components we have less knowledge on

\footnotetext{
${ }^{19}$ Please note that these labels are the interpretation of the researchers. We cannot prove claims like cooking the books; we merely have indicators that on average indicate the phenomenon at relatively higher proportions in certain sectors than in other sectors.
} 
Table 3 Top 10 sectors for each component of money laundering risk

\begin{tabular}{|c|c|c|}
\hline $\begin{array}{l}\mathrm{PC} 1 \text { - OC infiltration and } \mathrm{BO} \\
\text { secrecy }\end{array}$ & $\begin{array}{l}\text { PC2 - Opacity of business } \\
\text { ownership }\end{array}$ & PC3 - Cooking the books \\
\hline I 55 Accommodation & $\begin{array}{l}\text { N } 80 \text { Security and investigation } \\
\text { activities }\end{array}$ & Q 87. Residential care activities \\
\hline R 92 Gambling and betting & $\begin{array}{l}\text { S 95. Repair of computers and } \\
\text { personal ... }\end{array}$ & $\begin{array}{l}\text { R 90. Creative, arts and } \\
\text { entertainment }\end{array}$ \\
\hline H 51 Air transport & $\begin{array}{l}\text { R 90. Creative, arts and } \\
\text { entertainment }\end{array}$ & Q 88. Social work activities ... \\
\hline I 56 Food and beverage service & N 79. Travel agency, tour operator ... & R 92. Gambling and betting \\
\hline E 38 Waste collection, treatment... & $\begin{array}{l}\text { S 96. Other personal service } \\
\text { activities }\end{array}$ & $\begin{array}{l}\text { O 84. Public administration and } \\
\text { defence... }\end{array}$ \\
\hline $\begin{array}{l}\text { C } 23 \text { Manufacture of other } \\
\text { non-metallic... }\end{array}$ & $\begin{array}{l}\text { N 81. Services to buildings and } \\
\text { landscape... }\end{array}$ & Q 86. Human health \\
\hline $\begin{array}{l}\text { G } 47 \text { Retail trade, except motor } \\
\text { vehicles... }\end{array}$ & C 31. Manufacture of furniture & P 85. Education \\
\hline $\begin{array}{l}\text { O } 84 \text { Public administration and } \\
\text { defence... }\end{array}$ & $\mathrm{J}$ 63. Information service activities & $\begin{array}{l}\text { E 39. Remediation activities and } \\
\text { other... }\end{array}$ \\
\hline N 80 Security and investigation & $\begin{array}{l}\text { G } 47 . \text { Retail trade, except motor } \\
\text { vehicles ... }\end{array}$ & $\begin{array}{l}\text { A } 01 . \text { Crop and animal production, } \\
\text { hunting }\end{array}$ \\
\hline N 79 Travel agency, tour operator... & $\begin{array}{l}\text { M 74. professional, scientific and } \\
\text { technical... }\end{array}$ & $\begin{array}{l}\mathrm{R} \text { 93. Sports, amusement and } \\
\text { recreation }\end{array}$ \\
\hline
\end{tabular}

Source: calculated by the authors

what the expected sectors would be. Remarkable is that the art and entertainment sector scores high for both principal component 2 and 3, indicating that this sector consists of relatively profitable and cash-intensive businesses with more tax anomalies and more opacity.

We construct a synthetic composite indicator of money laundering risk by using as weight the proportion of variance explained by each component:

$$
\text { ML RISK COMPOSITE INDICATOR } i=\sum_{j=1}^{J}\left(S_{i j} \times w_{j}\right)=\left(S_{i 1} \times w_{1}\right)+\left(S_{i 2} \times w_{2}\right)\left(S_{i 3} \times w_{3}\right)
$$

where $i=1, \ldots, \mathrm{I}$ business sectors (in this case, $\mathrm{I}=83$ ), $\mathrm{j}=, \ldots, \mathrm{J}$ component (in our case, $\mathrm{J}=3$ ), and $\mathrm{w}_{\mathrm{j}}=$ proportion of variance (out of the total variance explained by the model) explained by each of the three components. Sij is the relevant value extracted by the PCA for each sector and for each component. Consequently, the composite score is normalized on a $0-100$ scale, where 100 indicates the highest risk. ${ }^{20}$

Table 4 shows the top 10 business sectors ranked according to the overall money laundering risk. The gambling sector scores the highest in our money laundering risk calculations. Casinos (and other gambling and gaming businesses, including video lottery and slot machine rooms) fall under (inter)national AML regulations, which means that they have to report unusual transactions and identify their customers. Even though this was not an obligation under the third AML directive, many countries in the EU have extended these duties to other gaming and gambling activities, because these activities are considered to bear a certain risk of money laundering (Unger et al. 2014, p. 23). The vulnerability of casinos for money laundering was recognized in the revision of the FATF 40 Recommendations, with obligations on casinos being significantly enhanced, and further acknowledged in the fourth EU AML directive. To

${ }^{20}$ Risk score $=($ composite score - lowest composite score $) /($ highest composite score - lowest composite score $)$ $* 100$ 
Table 4 Business sectors in the Netherlands with the highest money laundering risk

R 92. Gambling and betting activities

$\mathrm{R}$ 90. Creative arts and entertainment activities

$\mathrm{N}$ 79. Travel agency, tour operator reservation service, and related activities $\quad 54.1$

$\mathrm{S}$ 96. Other personal service activities

Source: calculated by the authors

back this up, the FATF published a report on these vulnerabilities of casinos and gaming sector (see FATF 2009).

The sector ranking second is accommodation, i.e. hotels. This is not surprising considering some recent literature and evidence (See e.g. Emergo 2011 for a study on the relation between crime and hotels in the Netherlands, more specifically Amsterdam). Third on the list is the creative arts and entertainment sector. Boot indicated already in 1994 that the creative arts and entertainment sector is almost perfect for money laundering, because it is one of the only sectors with a duty of confidentiality (see Boot and Wolde 1997, p. 32). This is confirmed by the fact that the art sector scores high on BO opacity, although Boot refers to the confidentiality of the customers, while our principal component refers to the 'confidentiality of owners'. The business sector of security and investigation agencies is fourth on our money laundering risk index. There have been several indications that outlaw motorcycle gangs are active in this sector (e.g. KLPD 2014, pp. 30, 34, 44, 66). Further down the list another business sector can be identified that has been mentioned in studies on money laundering cases in the Netherlands: bars and restaurants (see e.g. Ferwerda 2012; Emergo 2011; Savona and Riccardi 2015).

Sectors which do not directly deal with customers seem to score low (such as manufacturing, warehousing, fishing, and logging). A further analysis of the results shows that many manufacturing sectors are among the least risky sectors (10 manufacturing sectors have a risk score below 20). High barriers to entry, high capitalizations, low cash intensity, and the requirement of high (technical and human) skills might not be appealing to criminals wishing to launder their money (see also Savona and Riccardi 2017, p.84). This is in line with the finding that criminals mainly invest in businesses they are familiar with (Kruisbergen et al. 2015).

A result that can be rather surprising is that insurance and financial sectors ( $\mathrm{K} 65$ and $\mathrm{K} 64$ ) have a low money laundering risk. Both are among the regulated sectors under the AML policy regime. It cannot be concluded whether these regulations are targeted towards the wrong sectors or whether the AML efforts have been successful in lowering the money laundering risk in these industries. A third alternative - and more likely - explanation could be that the money laundering modi operandi which are most relevant and frequent for these sectors are not captured by the proxies of our analysis. Our data might be more related to more traditional methods of money laundering, like adding cash to the registry of a cash-intensive business. 


\section{Sensitivity Analysis}

In this section, we test the robustness and sensitivity of our results on three different levels. Ferwerda and Kleemans (2017) describe all the robustness and sensitivity analyses, while here we just list the main results. The main conclusion is that the results are robust. First, we test to what extent the results are driven by using an 'inductive' PCA (instead of a more 'theoretical' approach). To do so, we compare the results of the PCA against a model in which the nine different (normalized) proxy variables for money laundering risks are simply combined together without any further statistical technique. Our test indicates that our results are robust with respect to the use of the PCA; the results of the alternative model are very similar, with a correlation of 0.9 . Also, after testing other ways of adding up the variables, ${ }^{21}$ results are very similar.Second, we test to what extent the results are driven by the selection of variables. To do so, proxy variables are dropped, one by one, from the PCA model. This produces nine new composite scores which are compared with the baseline model. The correlation of the results of the baseline model with the nine alternative models are all very high (minimum correlation is 0.92), denoting that results are robust after controlling for the influence of variables' identification. Third, we test to what extent the results are driven by four specific methodological choices adopted in the PCA process: normalization techniques for the components and the final indicator, varimax or oblimin rotation, and weighting of the principal components. Since these 4 choices are independent of each other, 15 alternative PCAs are calculated. Comparing the results of these 15 alternative models with the baseline model indicates that our results are robust (minimum correlation is 0.96 ) to these methodological choices.

\section{Conclusions and Policy Implications}

The composite indicator for money laundering risk at the business sector level developed in this paper is helpful to better understand how the risks vary across different business sectors. It condenses a complex and multifaceted phenomenon such as money laundering into a single measure. A robustness and sensitivity analysis was carried out to verify whether the results of the analysis remain robust, even after making different assumptions and statistical choices. Results appear solid with respect to a) the decision to use an 'inductive' PCA instead of a more 'theoretical' approach; b) the selection of risk factors, and c) the choice of specific methodological parameters (related to the weighting, aggregation, and rotation). We conclude that the results of the analysis are robust. We have to stress, however, that the weakness of our approach is data availability, as you capture only those money laundering risks on which you have data. An example of preferred data refers to (confidential) actual BIBOB decisions for specific business sectors. Furthermore, data availability in the Netherlands is much better than in many other (European) countries, which would limit applications of the same model in other countries. The sector with the highest money laundering risk is the gambling and betting sector. Other risky economic activities are hotels, art, security agencies, repair of computers, hotels, bars, and restaurants.

\footnotetext{
${ }^{21}$ For example, one can first make a score for the threat variables (by adding them up and dividing by the number of threat variables) and adding them to a score for the vulnerability variables (by adding them up and dividing by the number of vulnerability variables). Similarly, the opacity proxies can be split from the other vulnerabilities to calculate separate scores and add them to a score for the threat variables.
} 
The indicators of money laundering risk could support the operational activity of both public agencies and private entities, for example (Savona and Riccardi 2017): policy makers, to better allocate AML resources and measures across the areas and sectors based on their risk level; investigative agencies, to identify the areas and sectors on which to strengthen monitoring and investigation; obliged entities (e.g. banks, professionals, etc.), to enrich the set of indicators and red flags to be used in AML customer due diligence (CDD). The most risky sectors stemming from the analysis in the Netherlands are generally not the ones that are at the moment specifically targeted with AML regulations (except gambling and betting). However, it must be noted that AML regulation is focused mainly on the placement phase of the money laundering process, while the risk factors considered in this paper seem to mainly focus on the integration phase. Even though the current AML regulations focus primarily on the gatekeepers of the financial system, this analysis can be used as a basis to strengthen the policies for the more risky sectors in a broader sense. For instance, the current administrative measure in the Netherlands (BIBOB) is restricted to a list of economic activities, ${ }^{22}$ which could be extended or revised according to our results. Indeed, some of the sectors that are generally selected for BIBOB procedures (hotels, bars, and restaurants) also score high in our analysis, although this could also relate to the fact that the BIBOB measures are included as one of the proxy variables in our methodology. Hence, this methodology can be used by policymakers, law enforcement agencies, supervisors, and FIUs to identify the most vulnerable business sectors. Furthermore, it can also supplement national risk assessments that have to be conducted to comply with the forty recommendations of the FATF (FATF 2012).

Acknowledgements We would like to thank Edwin Kruisbergen and Jan Glimmerveen for their help with obtaining the data. We would like to thank the editor and two anonymous reviewers for their helpful comments.

\section{Appendix 1}

Table 5 Correlation matrix of the variables used in the principal component analysis

\begin{tabular}{lcccccccccc}
\hline Variables & 1 & 2 & 3 & 4 & 5 & 6 & 7 & 8 & 9 \\
\hline 1. OC infiltration OCM & 1.00 & 0.21 & $0.28^{*}$ & -0.16 & -0.14 & -0.07 & -0.06 & 0.17 & -0.19 \\
2. OC infiltration OCP & 0.21 & 1.00 & $0.72^{*}$ & -0.04 & 0.21 & -0.06 & -0.10 & $0.25^{*}$ & -0.08 \\
3. Administrative denials & $0.28^{*}$ & $0.72^{*}$ & 1.00 & 0.02 & 0.18 & 0.01 & -0.05 & $0.42^{*}$ & -0.02 \\
4. Corporate tax anomalies & -0.16 & -0.04 & 0.02 & 1.00 & 0.17 & 0.17 & 0.13 & 0.08 & 0.02 \\
5. Cash intensity & -0.14 & 0.21 & 0.18 & 0.17 & 1.00 & $0.24^{*}$ & $0.24 *$ & 0.12 & 0.03 \\
6. BO distance & -0.07 & -0.06 & 0.01 & 0.17 & $0.24^{*}$ & 1.00 & $0.37 *$ & 0.15 & 0.09 \\
7. Shareholders' risk score & -0.06 & -0.10 & -0.05 & 0.13 & $0.24^{*}$ & $0.37^{*}$ & 1.00 & $0.50^{*}$ & -0.14 \\
8. BOs' risk score & 0.17 & $0.25^{*}$ & $0.42^{*}$ & 0.08 & 0.12 & 0.15 & $0.50^{*}$ & 1.00 & -0.09 \\
9. Profitability & -0.19 & -0.08 & -0.02 & 0.02 & 0.03 & 0.09 & -0.14 & -0.09 & 1.00 \\
\hline
\end{tabular}

Source: VU Amsterdam elaboration. * values are different from 0 with a significance level alpha of 0.05

\footnotetext{
${ }^{22}$ This list is not uniform across the Netherlands, since each municipality can determine its own list. In this sense, our approach could be useful to determine in a more systematic manner the list of economic activities to be monitored for BIBOB.
} 
Open Access This article is distributed under the terms of the Creative Commons Attribution 4.0 International License (http://creativecommons.org/licenses/by/4.0/), which permits unrestricted use, distribution, and reproduction in any medium, provided you give appropriate credit to the original author(s) and the source, provide a link to the Creative Commons license, and indicate if changes were made.

\section{References}

Rekenkamer, A. (2014). Combating money laundering: state in 2013. Retrieved from https://english.rekenkamer. nl/binaries/rekenkamer-english/documents/reports/2014/03/06/combating-money-laundering-state-in-2013 /Report+Combating+money+laundering+-+state+in+2013.pdf.

Blum, A. J., Levi, M., Naylor, R. T., \& Williams, P. (1999). Financial havens, banking secrecy and money laundering (Global programme against money laundering). Wien: UNODC - United Nations Office on Drugs and Crime Retrieved from http://www.cardiff.ac.uk/socsi/resources/levi-laundering.pdf.

Boot, A. W. A., \& Wolde, A. M. (1997). Witwassen in de Kunsthandel. Justitiële Verkenningen, 23(1), 32-40.

Decide. (2015). De bestrijding van witwassen. Beschrijving en effectiviteit 2010-2013. Startversie monitor antiwitwasbeleid.

EBOCS Consortium. (2015). European business ownership and control structures - final report of project EBOCS.

Emergo. (2011). De gezamenlijke aanpak van de zware (georganiseerde) misdaad in het hart van Amsterdam. Amsterdam: Boom Amsterdam.

EURODAD. (2015). Secret structures, hidden crimes: Urgent steps to address hidden ownership, money laundering and tax evasion from developing countries. Brussels: European Network on Debt and Development Retrieved from http://eurodad.org/files/pdf/1544288-secret-structures-hidden-crimes-urgentsteps-to-address-hidden-ownership-money-laundering-and-tax-evasion-from-developing-countries.pdf.

Europol. (2015). Why cash is still king? Den Haag: European police office Retrieved from https://www.europol. europa.eu/content/cash-still-king-criminals-prefer-cash-money-laundering.

FATF. (2009). Vulnerabilities of casinos and gaming sector. Paris: France Retrieved from http://www.fatf-gafi. org/media/fatf/documents/reports/Vulnerabilities\%20of\%20Casinos\%20and\%20Gaming\%20Sector.pdf.

FATF. (2010). Global money laundering \& terrorist financing threat assessment. Paris, France: Financial Action Task Force - Organization for Economic Cooperation and Development Retrieved from http://www.fatf-gafi. org/media/fatf/documents/reports/Global\%20Threat\%20assessment.pdf.

FATF. (2012). International Standards on combating money laundering and the financing of terrorism \& proliferation. The FATF Recommendations. Paris, France: Financial Action Task Force - Organization for Economic Cooperation and Development Retrieved from http://www.fatf-gafi. org/media/fatf/documents/recommendations/pdfs/FATF_Recommendations.pdf.

FATF. (2013a). FATF Guidance National Money Laundering and Terrorist Financing Risk Assessment. Retrieved from http://www.fatf-gafi.org/media/fatf/content/images/National_ML_TF_Risk_Assessment.pdf.

FATF. (2013b). National money laundering and terrorist financing risk assessment. Paris, France: Financial Action Task Force - Organization for Economic Cooperation and Development Retrieved from http://www. fatf-gafi.org/media/fatf/content/images/National ML TF Risk Assessment.pdf.

FATF. (2014a). FATF guidelines on transparency and beneficial ownership. Paris: Financial Action Task Force Organization for Economic Cooperation and Development Retrieved from http://www.fatf-gafi. org/media/fatf/documents/reports/Guidance-transparency-beneficial-ownership.pdf.

FATF. (2014b). Mutual Evaluation of the Netherlands: 2nd Follow-up Report. Retrieved November 6, 2016, from http://www.fatf-gafi.org/documents/documents/fur-netherlands-2014.html.

FATF. (2016). FATF report to the G20 on beneficial ownership. Paris: Financial Action Task Force Retrieved from http://www.fatf-gafi.org/publications/mutualevaluations/documents/report-g20-beneficial-ownership2016.html.

Ferwerda, J. (2012). The multidisciplinary economics of money laundering. Utrecht University. Retrieved from http://dspace.library.uu.nl/handle/1874/257920.

Ferwerda, J., \& Kleemans, E. R. (2017). Money laundering risks in the Netherlands. In E. U. Savona \& M. Riccardi (Eds.), Assessing the risk of money laundering in Europe, Final report of project IARM. Milano: Transcrime Retrieved from www.transcrime.it/iarm.

Ferwerda, J., \& Reuter, P. (2017). National Risk Assessments of Money Laundering: How Good and How Useful? Paper presented at the annual meeting of the European Society of Criminology 2017, Cardiff.

Ferwerda, J., \& Unger, B. (2016). 3 Organised crime infiltration in the Netherlands. Organised Crime in European Businesses, 35. 
Fijnaut, C., Bovenkerk, F., Bruinsma, G., \& Van de Bunt, H. (1998). Organized crime in the Netherlands. Boston: Kluwer Law International.

Gilmour, N. (2014). Understanding money laundering - a crime script approach. The European Review of Organised Crime, 1(2), 35-56.

Gilmour, N., \& Ridley, N. (2015). Everyday vulnerabilities. Money laundering through cash intensive businesses. Journal of Money Laundering Control, 18(3), 293-303.

Huisman, W., \& Nelen, H. (2007). Gotham unbound Dutch style. Crime, Law and Social Change, 48(3-5), 87103.

Kabacoff, R. I. (2015). $R$ in action. Data Analysis and Graphics with $R$ (second edition). Manning publications.

Kahneman, D. (2011). Thinking, fast and slow. New York: Farrar, Straus and Giroux.

Kaiser, H. F. (1960). The application of electronic computers to factor analysis. Educational and Psychological Measurement. Retrieved from http://psycnet.apa.org/psycinfo/1960-06772-001

KLPD (2014). Outlawbikers in Nederland. Woerden.

Kruisbergen, E. W., van de Bunt, H. G., \& Kleemans, E. R. (2012). Fourth Report of the Organized Crime Monitor. Retrieved from https://www.ncjrs.gov/App/Publications/abstract.aspx?ID=264680.

Kruisbergen, E. W., Kleemans, E. R., \& Kouwenberg, R. F. (2015). Profitability, power, or proximity? Organized crime offenders investing their money in legal economy. European Journal on Criminal Policy and Research, 21(2), 237-256.

Landelijk Bureau Bibob (2014). Jaarverslag 2014, Jusits, Ministerie van Veiligheid en Justitie.

Leung, K., \& Verga, S. (2007). Expert judgement in risk assessment.

Masciandaro, D., Takats, E., \& Unger, B. (2007). Black finance: The economics of money laundering. Cheltenham: Edward Elgar Publishing.

OECD \& JRC. (2008). Handbook on constructing composite indicators. Paris, France: Organisation for Economic Co-operation and Development - Joint Research Centre of the European Commission Retrieved from http://www.oecd.org/std/42495745.pdf.

Rencher, A. C. (2002). Methods of multivariate analysis (Second ed.). New York: John Wiley \& Sons.

Reuter, P. (2012). Draining development? Controlling flows of illicit funds from developing countries. World Bank.

Riccardi, M. (2014). When criminals invest in businesses: Are we looking in the right direction? An exploratory analysis of companies controlled by mafias. In S. Caneppele \& F. Calderoni (Eds.), Organized crime, corruption, and crime prevention - Essays in honor of Ernesto U. Savona. New York: Springer.

Riccardi, M., \& Levi, M. (2017). Cash and anti-money laundering. In Handbook of Criminal and Terrorism Financing Law.

Riccardi, M., \& Savona, E. U. (2013). Final report of project BOWNET-Identifying the beneficial owner of legal entities in the fight against money laundering networks. Trento: Transcrime - Università degli Studi di Trento Retrieved from http://www.bownet.eu/materials/BOWNET.pdf.

Savona, E. U., Riccardi, M., \& Berlusconi, G. (Eds.). (2016). Organised crime in European businesses. Abingdon: Routledge.

Savona, E.U., \& Riccardi, M. (2015). From illegal markets to legitimate businesses: the portfolio of organised crime in Europe. Final Report of Project OCP-Organised Crime Portfolio.

Savona, E. U., \& Riccardi, M. (2017). Assessing the risk of money laundering in Europe. Final Report of Project IARM (Report for the European Commission DG Home). Milano: Transcrime Retrieved from www. transcrime.it/iarm.

Soudijn, M. R. J., \& Akse, T. (2012). Witwassen Criminaliteitsbeeldanalyse 2012. Retrieved November 6, 2016, from https:/www.politie.nl/binaries/content/assets/politie/documenten-algemeen/nationaal-dreigingsbeeld2012/cba-witwassen-2012.pdf.

Soudijn, M. R. J., \& Reuter, P. (2016). Cash and carry: The high cost of currency smuggling in the drug trade. Crime, Law and Social Change, 66(3), 271-290.

Tax Justice Network. (2015). Financial secrecy index 2015 - methodology. Chesham: Tax Justice Network Retrieved from http:/www.financialsecrecyindex.com/PDF/FSI-Methodology.pdf.

Transcrime. (2013). Progetto PON Sicurezza 2007-2013. Gli investimenti delle mafie. Milano: Transcrime - Joint Research Centre on Transnational Crime.

Unger, B., Addink, H., Walker, J., Ferwerda, J., Van den Broek, M., \& Deleanu, I. (2013). Project 'ECOLEF' The Economic and Legal Effectiveness of Anti-Money Laundering and Combating Terrorist Financing Policy final report for the European Commission.

Unger, B., Ferwerda, J., van den Broek M., \& Deleanu, I. (2014). The economic and legal effectiveness of the European Union's anti-money laundering policy. Edward Elgar Publishing.

Unger, B., \& Rawlings, G. (2008). Competing for criminal money. Global Business and Economics Review, $10(3)$. 
U.S. Department of the Treasury. (2015). National money laundering risk assessment. Washington DC: Department of the Treasury Retrieved from https://www.treasury.gov/resource-center/terrorist-illicitfinance/Documents/National\%20Money\%20Laundering\%20Risk\%20Assessment\%20\%E2\%80\%93 \%2006-12-2015.pdf.

van der Does de Willebois, E., Halter, E. M., Harrison, R. A., Park, J. W., \& Sharman, J. C. (2011). The puppet masters: How the corrupt use legal structures to hide stolen assets and what to do about it. The World Bank. Retrieved from http://elibrary.worldbank.org/doi/book/10.1596/978-0-8213-8894-5.

van der Veen, H. C. J., \& Ferwerda, J. (2016). Verkenning methoden en data National Risk Assessment Witwassen en Terrorismefinanciering. Cahiers, 2016-2012.

van der Veen, H. C. J., \& Heuts, L. F. (2017). National Risk Assessment Witwassen. Cahiers, 2017-2013.

van Koningsveld, T. J. (2015). De offshore wereld ontmaskerd: Een studie naar aard en omvang van het misbruik maken van offshore vennootschappen door Nederlandse (rechts) personen. Retrieved from http://www. narcis.nl/publication/RecordID/oai:tilburguniversity.edu:publications\%2Fd0618f87-8dee-49c2-b1cb-63c5 cedf983f.

Williams, P. (2001). Transnational organized crime, illicit markets, and money laundering. In P. Simmons \& C. Ouderen, Challenges in international governance (pp. 106-150). Washington DC: Carnegie Endowment. Retrieved from http://carnegieendowment.org/pdf/files/mgi-ch3.pdf 